\title{
Presence of the Gift
}

\section{Ann Game and Andrew Metcalfe}

Possibly the most important concept in social and cultural theory, the gift is also the most frequently misunderstood. Philosophers and social and cultural theorists from a range of traditions have followed Mauss in assuming that gifts always entail obligatory exchanges between distinct parties who give, receive and reciprocate, and, that the social and cultural emerges through this sequence of obligations. ${ }^{1}$ In this article we will consider the alternative ideas that non-exchange gifts are not only possible but the basis of social and cultural life. We will invert the logic of exchange theory by asking if the social and cultural arises from the nonsequential giving-and-receiving of a gift relation.

To develop an understanding of non-exchange gift relations, we need to approach the abstractions of exchange theory through the direct experience of participants in the gift. ${ }^{2}$ Accordingly, we will draw on a research project on the phenomenology of teaching, for which we interviewed thirteen well-known Australians and twenty-two teachers, the latter coming from all levels of formal education and a diversity of disciplines. ${ }^{3}$ In semi-structured interviews, we invited all interviewees to talk about their experiences of life-changing teachers, and the teachers to talk about their own teaching practices and experiences. The teacher's gift was one of the most persistent themes in our interviewees' descriptions of teachers, drawing attention to the fact that the gift underlies all creative relations. 
While interviewees spoke of the gift in exchange terms, they also spoke of nonexchange gifts; that is, of classroom experiences in which there is a giving and receiving that is neither sequential nor locatable, experiences where learning happens, but not through the volition of any one. They spoke of a classroom energy and vitality that does not accord with Euclidean space or linear time, that is characterised by stillness and wholeness and not by restless oscillation. This is an experience of grace that is compromised by attempts to teach toward the attainment of predetermined outcomes.

\section{-FROM GIFT EXCHANGE TO THE GIFT}

Our analysis relies on a distinction between a logic based on exchange and identity and a logic based on relations. It is the latter, we argue, that is the basis of the gift. Relationality is an inclusive logic that, while acknowledging the existence of exchange, also opens conceptual possibilities unimaginable within the exchange model.

An exchange model presumes that all relations, whether gift or commodity based, are interactions between separate identities:

The activity of giving belongs to a group of activities that presuppose a subject, a dative, and a direct object: a giver gives a gift to someone who, through this giving, is invited (asked, urged, demanded, forced) to receive the gift'. ${ }^{4}$

Ontologically, this social world is implicitly Hegelian, comprised of finite subjects and objects, located in Euclidean space and linear time, bound and alienated by desires, debts and obligations. By presuming that identities pre-exist relations, exchange theorists try to derive the social from the non-social and the cooperative from the competitive. In the process they do away with the gift, replacing it with gift exchange.

This derivation of the social from the non-social is given its classic formulation in the short meeting story that Mauss tells in his conclusion to The Gift. 'Two groups of men who meet', Mauss says, 'can only either draw apart, and, if they show mistrust towards one another or issue a challenge, fight-or they can negotiate.' 
The people of Kiriwana told Malinowski: 'The men from Dobu are not good like us; they are cruel, they are cannibals. When we come to Dobu, we are afraid of them. They might kill us. But then I spit out ginger root, and their attitude changes. They lay down their spears and receive us well.' Nothing better interprets this unstable state between festival and war. ${ }^{5}$

Mauss tells this story to show how society develops by 'substituting alliance, gifts, and trade for war, isolation and stagnation'.6 The fact that giving, receiving and reciprocating are apparently voluntary and yet also obligatory ties groups together through time. Gift exchange allows people 'to oppose and to give to one another without sacrificing themselves to one another'. ${ }^{7}$

The reduction of the gift to gift exchange is evident in Mary Douglas's claim that 'There should not be any free gifts. What is wrong with the so-called free gift is the donor's intention to be exempt from return gifts coming from the recipient. Refusing requital puts the act of giving outside any mutual ties'.8 Thus, in this account, a pure gift is a social impossibility.

A similar logic leads Derrida to say that the gift itself is impossible, always annulled by the obligation to reciprocate: 'For there to be a gift, there must be no reciprocity, return, exchange, countergift, or debt.'9 This aporetic 'paralysis' of the gift in Derrida's account derives from his Hegelian assumptions about the desire for identity and negation of otherness. ${ }^{10}$ Derrida assumes that gifts necessarily involve desires and intentions: 'There is no gift without the intention of giving'; 'some "one" gives some "thing" to some "one other".'11

It supposes a subject and a verb, a constituted subject, which can also be a collective ... a subject identical to itself and conscious of its identity, indeed seeking through the gesture of the gift to constitute its own unity, and, precisely, to get its own identity recognized so that that identity comes back to it. 12

While a pure gift, according to Derrida, would elude the world of subjects and objects ('if there is a gift, it cannot take place between two subjects exchanging objects'), the impossibility of this alternative ontology annuls the gift. Thus, he concludes, a 'consistent discourse on the gift becomes impossible'.13

According to Derrida, the only way out of this paradox, which is no way out, is the gift of time-delay, deferral and the time to forget: 'the gift only gives to the 
extent that it gives time'.14 'For there to be a gift, not only must the donor or donee not perceive or receive the gift as such, have no consciousness of it, no memory, no recognition; he or she must also forget it right away'.15 This forgetting must also include the forgetting of the desire to forget: desire is given ontological primacy, and the Hegelian presumption of linearity remains. ${ }^{16}$ Even where there is a gift circle, Derrida assumes that there must be a Euclidean, chronological point of origin, a locatable subject: 'What is the gift as the first mover of the circle? And how does it contract itself into a circular contract? And from what place? Since when? From whom?'17 Any claim of simultaneity of giving and receiving would be treated with suspicion, regarded as a manifestation of the metaphysics of presence. Within Hegelian logic, meeting is mirroring, a manifestation of the desire for self-sameness; the possibility of meeting with difference is precluded.

Cixous offers another example of exchange logic in poststructuralist thought. She also retains the basic Hegelian formulation of desire in her account of the abundance of the feminine gift. The undoing of exchange consists in an excess: feminine subjectivity exceeds the masculine economy and logic of desire. The 'economy of femininity' is an 'overflowing', an 'open, extravagant subjectivity', a 'relationship to the other in which the gift doesn't calculate its influence'.18

How does she give? What are her dealings with saving or squandering, reserve, life, death? She too gives for. She too, with open hands gives herself-pleasure, happiness, increased value, enhanced self-image. But she doesn't try to 'recover her expenses.' She is able not to return to herself, never settling down, pouring out, going everywhere to the other. ${ }^{19}$ Although Schrift claims that Cixous challenges the classical exchange assumptions of the gift, by allowing for the possibility of giving without expectation of return, the notion of excess she shares with Bataille and Derrida presumes the finitude and linearity of desire. ${ }^{20}$ For poststructuralists, excess simply goes beyond boundaries; it is a 'more than' and 'elsewhere'. Most significantly, this tradition retains the assumption of subjectivity: it is a subject who gives excessively. As we will show, these presumptions make the relational ontology of the gift unthinkable.

The distinction we want to make between exchange and relational logics can be understood in terms of Martin Buber's distinction between I-It and I-Thou. Buber used the term I-It to describe the desirous logic of the Hegelian world of finite 
subjects and objects located in linear-Euclidean time-space. The world of the I-Thou relation, by contrast, is based on infinitude and love. I-Thou refers to a primary relationality:

It exists only through being bounded by others. But when Thou is spoken, there is no thing. Thou has no bounds...

The relation to the Thou is direct. No system of ideas, no foreknowledge, and no fancy intervene between $I$ and Thou... No aim, no lust, and no anticipation intervene between $I$ and Thou... ${ }^{21}$

In an I-Thou relation there are no identifiable subjects and objects; the world is not a set of external things but a whole that is always emerging through meetings. This is a situation where things happen relationally without arising from a subject's volition. Whereas Derrida claims that a gift must be intended, Buber insists that 'The life of human beings ... does not exist in virtue of activities alone which have some thing for their object'.22

It is the suspension of a subject's desire for an object that makes Buber's IThou a relation of respect and love: 'Love is between $I$ and Thou ... Love is responsibility of an $I$ for a Thou'.23 This love is not subjective but relational, a way of being that arises between me and you, not something we do but a state that we are in. Love is infinite, not because it is excessive, but because it is based on nothingness. It is this non-desirous, non-volitional quality of I-Thou that makes it the basis of the gift:

The Thou meets me through grace-it is not found by seeking...

The Thou meets me. But I step into relation with it. Hence the relation means being chosen and choosing, suffering and action in one...

The primary word I-Thou can be spoken only with the whole being. Concentration and fusion into the whole being can never take place through my agency, nor can it ever take place without me. I become through my relation to the Thou; as I become I, I say Thou.

All real living is meeting. ${ }^{24}$

Once desire is suspended by love, the experience of time is transformed. Whereas desire is governed by a fantasy of future fulfillment, love accepts what is. The time of an I-Thou meeting is the non-chronological present: 
The present, and by that is meant not the point which indicates from time to time in our thought merely the conclusion of 'finished' time, the mere appearance of a termination which is fixed and held, but the real, filled present, exists only in so far as actual presentness, meeting and relation exist. The present arises only in virtue of the fact that the Thou becomes present. 25

In this time, the unfolding present holds within it all time. In contrast to chronological or linear time, the past here is not a flashback to what has been and the future is neither anticipation of what is to come nor Derrida's deferral: past and future exist in the eternal as phenomena of the present. This, as Buber suggests, is the time of presence, the time of being, the time of the fullness of living. ${ }^{26}$ It is the fullness of time in the present that allows the simultaneity of giving and receiving in the gift.

Derrida's suspicion of the present is based on his presumption of linear time: he readily demonstrates that the present of linear time can never be identified, but only endlessly represented. Buber's present by contrast is the eternity that linear time presupposes. ${ }^{27}$ It is the temporal counterpart to infinitude. The present is where life is given; it is experienced as a presence, as a whole that cannot be contained by identification or representation. This non-containable quality of presence is what makes the gift elusive to exchange theorists.

\section{-THE CLASSROOM}

Our phenomenological study of teaching was not designed to be representative or to provide data from which generalisations could be drawn, but, rather, to provide details of particular experiences and situations, through which we might gain a sympathetic understanding of the universality of good teaching. Whereas generalisation is static abstraction, universality is lived reality, the whole that is experienced through participation and particularity. Our writing, then, is guided by a participatory principle, aiming to evoke the quality of experiences so that they might resonate with those of readers. By inviting readers to reflect on the similarities and differences with their own experiences, this form of writing allows for a creative dialogue with the text.28 
To develop an appreciation of the difference between gift exchange and the gift, we will consider two accounts of classroom experiences, one from a student, the other from a teacher. These experiences were common among our interviewees, but by focusing on case studies the article aims to provide the particularities that readers need in order to literally get a feel for the conceptual issues involved.

This is how radio broadcaster Julie McCrossin described her life-changing teacher, Mrs Miller:

Passion, patience and boundless personal relationship with each girl, they're the three qualities of a great teacher like Mrs Miller. The most passionate, erudite, curious hunger for learning: that was the spirit I got from Enid Miller and it's alive and well.

The passion-she communicated a love of reading, of literature, of performance in particular, particularly Shakespeare. She wasn't bunging it on, she was absolutely authentic. And the patience-she had a faith in our ability to do class performances: we did whole plays in class; it was a very oral experience. I think she loved teaching, I think she loved the English language and I think she loved the girls, in a pure sense.

What I mean by really teaching is the ability to arouse, to stimulate to learn, so that the student is enthusiastic, electrified. Good teachers have a gift, a vocation, and the core of it for me is that they want you to learn as much as they want to learn themselves. They really care, and that's the human connection. In fact it goes deeper than that. Mrs Miller thought she could learn from students. She felt how Julie and the others responded to the trauma of Lady Macbeth and in this way she could experience the trauma of Lady Macbeth afresh.

She had been teaching for years, but she knew every girl by name and made everyone feel special. You really felt she cared about you and she wanted you to understand Shakespeare and to feel that the drama of Macbeth and the witches were all about you-a marvellous gift.

And the final thing I will say is that she was just hilariously idiosyncratic. She was clearly a smoker, desperately thin. Looking back, her agitation must have been a desire to smoke. And she had very overt phobias. She 
was terrified of birds and if a bird ever flew past a classroom, Mrs Miller almost had a nervous breakdown. That only endeared her to us more. She was a very quirky individual, Mrs Miller.

It's a miracle in a way, her personal passion, her knowledge of her material, her love of learning and teaching were all so strong that even though she was very lined and old, battered by life, she could reach across this extraordinary gap to these teenagers.

Here is primary school teacher, Sharon Cheers, who, as a young teacher, was inspired by a senior colleague, Alison Pegus:

She had an amazing connection with the kids. She challenged every single one of them. She catered for every child. And I think that core relationship was probably more important than her actual knowledge of all the different teaching theories. That made it easy for her to implement them.

Alison was a gifted teacher. As soon as you walked into her classroom, you could tell it was working. There was lots of movement, lots of different things happening, but there was still a sense of calm. It's a feeling more than anything. You could tell she was not just listening for the sake of listening, but really listening to understand what's going on for that child. I suppose her passion came through everything she did.

Speaking of her own experiences as a teacher, Sharon said:

There comes a time when I say I've got them now. And when I feel that I've got them, I feel that I know what they're going to need. That's the thing about term one. You create a unit, you're organised, but you don't really know the kids, so you're constantly shifting things. You've got to get it to the stage where they can work together as a whole and accept the difference in each other. That's when you can see amazing opportunities.

Before there's a shift you can find you're giving but you don't get back. And, if you've got kids that are very worried about themselves and not thinking of others, they take, and that drains a teacher's energy. I think teachers can burn out very, very easily because teachers give of their time. You give, give, give and give, and then the holidays come and then you collapse. 
Each class is different. Some groups are more understanding of the differences in the class than others. Some classes thrive, like the one I had last year, but this year's class has taken months longer to get to the same sense of community where everyone is respected.

I suppose once you've got them, you can relax. You can give and you get back and it becomes this sort of reciprocal relationship of knowing and understanding, and it's meaningful. It's an openness. If they're giving, they're also open to feedback, they're open to change. They get to a point where they say Oh yeah, I've got it. There's a sense of confidence. It's when you're explaining something and they smile or they look at you. It's those funny moments that keep you going. That's the giving. That's when you see something happening in the classroom that's really exciting. I suppose you just sort of ride this energy and that momentum carries you through.

If you see the children as whole people, not as something that we're trying to mould into something else, you work with what you've been given. And I think that requires an openness and a willingness. And I don't think everyone has that. The special moments and the giving you receive have an immense impact, so ultimately they are changing my life and keeping the sense of wonder alive for me-indeed a precious gift.

\section{—WHO GIVES AND WHO RECEIVES? WHERE IS THE GIFT?}

Like all the people we interviewed, Julie and Sharon repeatedly spoke of gifts: of giving and receiving, generosity, gratitude, giftedness, grace, acceptance, reciprocity, feedback, openness. When people use these terms, they sometimes identify givers, recipients, and the gift that passes between them, but often they use language that associates the gift with a suspension of location, subjects and objects. These different usages point to different experiences of the gift which we will consider in connection with the gift of classroom energy.

Teachers like Alison Pegus and Mrs Miller are invariably characterised by their special energy, often described in terms of what Cixous might call the 'open, extravagant subjectivity' of the teacher: teachers have an abundance of energy and knowledge which they give to students. The teacher's role is to give students enough 
energy and knowledge to enable them to reach a level where they too can enter exchange economies, either gift or commodity based.

In this model, teaching is an active putting out and the good teacher is the one who gives most. Sharon is speaking in these terms when she says that teachers 'give, give, give and give' until they have nothing left to offer. When she says that 'holidays come and then you collapse', she is noting that teachers who go into deficit have to recoup their energy elsewhere. Despite Bataille's claim that a gift principle of expenditure and loss is contrary to market principles of balanced accounts and gains, excess is based on an accountancy model that identifies who gives, who receives and what is given. ${ }^{29}$

If there are examples of excess in Sharon's description, there are also instances of genuine infinitude, which is the ontological state of creativity. She speaks of the class coming together in terms of an ontological 'shift', a moment when there is a change in space and time. She characterises this shift in terms of relaxation, openness to change, a lively sense of wonder, shared looks, openness to feedback, working together as a whole and accepting the difference in each other. This is a transition from the exchange logic of I-It to the relational logic of I-Thou, from a situation of identifiable givers and receivers to one where there is a gift but you cannot say who is giving what to whom; a transition from the finitude and quantification of gain and loss to the infinitude of creative unfolding. The reciprocity of which Sharon speaks is not one of delayed return, but a simultaneous giving and receiving that is neither sequential nor locatable. This simultaneity is not a finished moment in linear time, for, as we will show in the later discussion of the living spirit of the teacher, classroom experiences of giving and receiving are always unfolding. Classroom energy, then, comes not from the teacher, but from the relation. This is the logic of the gift without exchange.

Passion is the term that describes this gift of energy. Passion, like love, is a word commonly confused with desire and excessive subjectivity, but as its etymology implies, it is an energy that involves passivity, suffering and acceptance. Passion suspends subjecthood; it is something received, something that moves you mysteriously, not something that you do or choose.

Buber alludes to this suspension of subjectivity when he says that the grace of the I-Thou relation 'means being chosen and choosing, suffering and action in 
one'. ${ }^{30}$ This is exemplified by the listening of Alison Pegus: 'You could tell she was not just listening for the sake of listening, but really listening to understand what's going on for that child. I suppose her passion came through everything she did.' This passionate listening is both a giving and receiving: her listening speaks, allowing the classroom dialogue to find the words it needs. In this dialogue, there is no identifiable listener distinct from an identifiable speaker; there is no restless oscillation between listening and speaking. When grace is present, as it is in Alison's classroom, there is 'lots of movement ... but there is still a sense of calm'. In the creative unfolding of the classroom dialogue, every utterance implies the emerging whole. ${ }^{31}$ The participation of each participant draws out a difference in the whole, but because people are not acting as individuals, no one can identify who gives what.

Sharon says that this creative learning cannot occur until she and the students 'accept the difference in each other'. Until this moment of meeting in the gift, lessons are not lessons for this class. They do not address the needs of this particular situation. So Sharon attends patiently, accepting the different dynamics of each class, looking for the change signalled by a smile, a warmth, a relaxation, a change in body language. There will be a moment of getting it when the class comes together and comes alive. Once this lively relationship exists, both teachers and students are able to receive what is being given to them.

The student's smile of getting it is a receiving of knowledge and also, as Sharon says, 'an open giving' to the classroom relationship that has offered this knowledge. The student is unselfconsciously giving thanks for what they receive. In giving of themselves, they receive what they need; in accepting what they need, they give the teacher and the class what they need to carry on. There is a gift but you cannot say who is giving what: there is a wave of energy but no effort, desire, intention or sense of sequence.

Whereas the exchange model sees giving as the origin and acceptance as subsequent, Sharon shows that where there is acceptance there is always also giving. ${ }^{32}$ The gift doesn't accord with a model of active subjects in linear time. It occurs in the classroom in moments of grace. Sharon's metaphor for this grace might be taken from surfing: 'you just sort of ride this energy and that momentum carries you through'. The openness of this experience suspends the insides and outsides of 
Euclidean space: participants are both carrying the energy and are being carried by it. They are at once still and on the edge, being drawn on, in fascination.

\section{-AcCEPTANCE}

Sharon's experience draws attention to the importance of acceptance in school life. She says, 'If you see the children as whole people, not as something that we're trying to mould into something else, you work with what you've been given. And I think that requires an openness and a willingness.' Acceptance of the difference offered by each participant is itself a giving, a giving of attention and respect, a giving up of subjecthood and desire. The acceptance of difference is the acceptance of others as whole people. $^{33}$ In contrast to the principle of sameness entailed in totality, wholeness emerges from this meeting with difference.

As an opening of the boundaries upon which subjectivity and identity rely, acceptance is distinct from the post Hegelian understanding of intersubjectivity. For, to affirm the other's subjectivity, as Levinas points out, is to refuse to accept their wholeness, to remain closed and ungiving to true difference. The other's wholeness is only accepted when desire and subjectivity are suspended, in what he calls a faceto-face meeting:

You turn yourself toward the Other as toward an object when you see a nose, eyes, a forehead, a chin, and you can describe them. When one observes the colour of the eyes one is not in social relationship with the Other...

There is first the very uprightness of the face, its upright exposure, without defence. The skin of the face is that which stays most naked, most destitute. It is most naked, though with a decent nudity. It is the most destitute also: there is an essential poverty in the face...

The face is ... signification without context. I mean that the Other, in the rectitude of his face, is not a character within a context ... a professor at the Sorbonne, a Supreme Court justice, son of so-and-so ... Here, to the contrary, the face is meaning all by itself. You are you. In this sense one can say that the face is not 'seen'. It is what cannot become a content, which your thought would embrace; it is uncontainable, it leads you beyond. ${ }^{34}$ 
When Levinas says 'you are you', he is not associating you-ness with an identity or subject. The word you is like the words now and here: it indicates a presence that can be experienced as a whole but can never be defined, contained, or represented in absentia. You is a participatory word which emerges from meeting, as part of a relationship. Levinas is talking about an I-Thou relation: 'I become through my relation to the Thou; as I become I, I say Thou. All real living is meeting.' 35

Within this open and accepting relation there is a mysterious incapacity to say where the boundaries of sameness and difference fall. The other fills me with wonder, yet this wonder teaches me about the strangeness of my being: the boundaries between inside and outside are suspended, revealing ecologically how everything is implicated in everything else. ${ }^{36}$ I see beyond your identity to your undefended essence or beingness. You are a professor, but that means you are also a student. You are more than any thing; you are no-thing. While the identities of the IIt are acknowledged, therefore, the respect of the I-Thou is never simply a matter of affirming identity or subjectivity. Respect is always awareness of your difference even to the way you identify yourself. This is why it is not earned or forfeited, and does not arise from the accounting of exchange modes.

Mauss and many other studies of the potlatch have shown the jealousy and competition that accompany the finite logic of I-It,37 but because the I-Thou is infinite, gifts take place in moments of incomparability. ${ }^{38}$ Respect for one child is not a threat to others, but respect for the unique part each plays in the whole. Sharon says: 'You've got to get it to the stage where they can work together as a whole and accept the difference in each other. That's when you can see amazing opportunities.' The teacher's capacity for 'boundless personal relationship with each student' is not based on the finite logic of excessive subjectivity, but rather on the humble emptiness of Levinas's face-to-face meeting. Acceptance is not located in a sequence of giving then receiving: the acceptance is the giving.

In giving up subjecthood to accept others, participants in a classroom accept the gift of who they truly are. In contrast to the exchange model of gains or losses to the self, the gift of acceptance involves a giving up of the self. When you meet others, the relation allows you to be with the strangeness, the vulnerabilities, the shadow that you negate when desiring self-certainty: you accept your wholeness without balancing credits and debits. The gift is the capacity for surprise. As Sharon says: 
'The special moments and the giving you receive have an immense impact, so ultimately they are changing my life and keeping the sense of wonder alive for meindeed a precious gift'.

To show how far this is from Cixous' model of excessive subjectivity, we will look at Julie McCrossin's account of Mrs Miller's 'gift or vocation'. This gift is a call that Mrs Miller has accepted. It offers her a world where she is accepted. Her gift is her openness to receive from the classroom what she needs. Julie draws attention to this question when she adds a description of Mrs Miller's idiosyncrasies to her account of the three qualities that make Mrs Miller a great teacher. The apparent discrepancy between the 'agitated' and 'quirky' individual and the passionate and patient teacher tells us about the transformative power of classroom relations. ${ }^{39}$ Through their relation with her, students give Mrs Miller qualities that are not available to her on her own. When the students experience Mrs Miller's enthusiasm for Shakespeare, they do not look at her age or 'lined face': she meets them across the 'extraordinary gap' because she is not limited by such definitions.

The point is not that good teachers are successful despite their vulnerabilities. To be real with students, to enter the class with the passion of openness, Mrs Miller has to accept who she is, including apparent weaknesses. ${ }^{40}$ As Gaita observed, the teacher's gift comes from love, humility and emptiness, and not from the desire of an overflowing subjectivity:

teachers who set out to inspire have their attention in the wrong place and are too distracted from their subject to be able to offer anything deep no matter how many hearts they set afire ... Just as charity is corrupt unless it is motivated by the needs of another rather than by the desire to do something charitable, so teachers inspire their students into a proper love of what they are doing by the manner of their attention to their subject rather than by setting out to inspire them. ${ }^{41}$

Mrs Miller's giving is not strategic or intentional. It is the 'absolutely authentic' connection she shares with students. ${ }^{42}$

\section{-PRESEnCE}

Gift exchange is based on individuals, on the distance of elsewhere, and on the past of debts and the future of expectations. By contrast, the gift accepts what is. 
Acceptance takes us to the present, to the reality of life, experienced without the abstraction, calculation and fantasies that are characteristic of subjectivity, Euclidean space and linear time. The present-prae esse-is to be at hand. The gift is the present, here, now, where being is offered, where I meets Thou, where difference presents itself. Presence is the presence of mystery; it calls for our full attention.

Presence involves patience, a particular way of being in time, and patience, in turn, is etymologically connected with passion through suffering: patience is an acceptance or suffering of time. It is the openness that makes it possible to stay in the present without being distracted by the desirous fantasies of subjectivity. Julie makes this connection when identifying patience, passion and 'boundless personal relationship' as the three qualities that underlie Mrs Miller's gift.

The passive element of presence, then, is not an unlively condition: it is the passivity of passion. It manifests a lively hope, not based on desire for finite outcomes, but on an interested engagement with the world. The hope in patience knows that it will find in tomorrow what it is not in a position to expect today, and yet find it as the fulfilment of the as yet unknown significance of the present. The temporality of patience thus escapes exchange theory with its emphasis on restless oscillation and linear time.

To appreciate this temporal difference, let us imagine Mrs Miller's students performing Shakespeare in class. Neither Mrs Miller nor the students rush to interpret Shakespeare, with a view to a future exam. They simply devote themselves to the particular lines of speech before them, playing with them until they ring true. Patience suspends linear time: interested to see what they will learn about Lady Macbeth and about themselves, Mrs Miller and the students accept that the only life available is the one that unfolds from here and now. This class matters. It is not a lesson about life: it is life, it is the world.

The patience of the passionate classroom is, then, a form of presence. Students and teachers know that everything they need is already here; they know, too, that what they need will not be what they could have anticipated. As Buber says, awaited answers cannot be received. The answer comes:

not from a distance but from the air round about me, noiselessly ... Really

it did not come; it was there. It had been there-so I may explain it-even 
before my [question]: there it was, and now, when I laid myself open to it, it let itself be received by me ... If I were to report with what I heard it I should have to say 'with every pore of my body'.43

The lines spoken in Mrs Miller's class resound when a sense of presence gives them universality. Whose body is it that 'struts and frets his hour upon this stage'? Is it Shakespeare's? Julie's? Macbeth's? Western civilisation's? Mrs Miller's? The unanswerability of this question demonstrates the openness, and suspension of subjecthood, that allows the class to be true to both Shakespeare and the students. Julie says: 'You really felt she cared about you and she wanted you to understand Shakespeare and to feel that the drama of Macbeth and the witches were all about you-a marvelous gift.' It is the particularity in this experience-Levinas's 'you are you' - that gives it the quality of universality. 44

The 'marvellous gift' emerges from the experience of presence. It is not based on a finite knowledge exchanged between parties, nor is it the endless deferral of knowledge discussed in poststructuralist accounts of the gift. It is infinite, not because it exceeds what can be measured, not because it is elsewhere, but because it involves the creative transformation of face-to-face meeting.

The significance of this gift can be understood in terms of Steiner's distinction between presence and the distance or pastness of representation: art is lived, here, now, as a real presence. ${ }^{45}$ With the suspension of chronological time, this is a creative experience of the living presence of the past. So while Derrida insists that the origin is always deferred, that any notion of originality is associated with the metaphysics of presence,46 Steiner argues that creative performance is simultaneously new and original, originary. Whereas Derrida sees presence as selfsameness, and therefore impossible, Steiner sees it as a transformative meeting with difference. This explains how Shakespeare stays alive for Mrs Miller despite years of teaching the 'same' plays. The unique part played by students like Julie reveals new aspects of the play's potential, a potential that has always been there and yet comes into being in the present performance. 47

As the play is transformed, so are the performers. Steiner emphasises that, in an experience of presence, we are directly addressed by the other, as I to Thou. The work of art asks of us: 'What do you feel, what do you think of the possibilities of life, of the alternative shapes of being which are implicit in your experiences of me, in 
our encounter?'48 In this way we are called to return to the reality of our life and treat life with respect. This relation between call and response involves the same logic as that between giving and receiving. This is not a sequence but a simultaneity: to hear the call is to have responded. 49

This sense of calling and responsibility is quite different to the alienated sense of obligation and duty found in analyses of gift exchange that take the giver's choice and freedom as the starting point. These analyses rest on a paradox: gift exchange involves actions that are both voluntary and obligatory. From a relational perspective, however, the gift does not emerge from a voluntary act and there is no external requirement to give or reciprocate. Rather, the gift emerges as a response to a call from the difference of the whole. When experienced as a gift, society is not an external entity over and above the individual or subject, but is the infinite process of sociality in which people play their unique part.

In a classroom like Mrs Miller's, it is this sense of calling that makes work meaningful. The teacher's open offering of herself to her calling calls students to offer their full participation. There is, as Murdoch suggests, no question of whether this call should be followed, for the being who hears the call is no longer in the ontological form of the reserved, choosing and volitional subject. To hear the call is to recognise immediately the order of wholeness from which it comes and to know its 'goodness', which, Murdoch says, has the quality of 'naked' 'for-nothingness'. This 'for-nothingness' challenges the time, space and ontology of purposive moral action, acknowledging the gratuity of the life process in which we participate. For Murdoch, the virtue of goodness is 'an attempt to pierce the veil of selfish consciousness' and respond to the 'world as it really is', recognising 'the minute and absolutely random detail of the world ... [and its] sense of unity and form'.50 With presence we do not simply return to life, we return with an awareness of the significance of our part in the whole. This awareness of wholeness is often experienced as holiness.

\section{-UNFOLDING AND OUTCOME}

Neoliberal models of education are based on the logic of gift exchange, that is, on the expectation of reciprocity, the future return from a present gift. This is a mechanism for holding difference at bay: the moment of return promises to redress the difference made by time, to guarantee that the future is a return of the present. The 
logic suggests insurance: education is not seen as creativity, difference and learning but as guarantee, perpetuity and repetition.

In our research, we found that good teachers like Sharon, Alison and Mrs Miller were aware of the unhealthy nature of their pedagogic strategies and expectations, however well-intentioned these may have been. Through concentrating on potential rather than expectation, through patience rather than a desire for pre-established outcomes, teachers learn to live with the unknowing that comes with presence. When we asked Sharon, for example, what she saw in her students, she spoke of their blooming, and described it in a way that reminded us of Levinas's account. Her teaching relies on the openness that leaves her amazed by the gratuitous and unpredictable particularity of every student. Education is based for her on difference and not sameness:

You can definitely see talent in people, but you can also see them as a person. That constantly amazes me. You can go down to that preschool and their personalities are there. They are true little people. So in saying you can see their talent, you can certainly see aspects of their personality that are strong, but whether or not that's a talent or just them, I don't know. In terms of something that you measure, in terms of competition, I wonder: Competition in what? Competition in being a good person? Competition in being able to answer closed questions correctly? How do you measure a good thinker against a better thinker? You can always set something you can measure and then compare students against that, but that's leaving out a whole lot. I suppose that's the whole other thing, how do you measure education?

Sharon's teaching draws, no doubt, on an undefined range of hopes for her students. She might hope they will be successful in their careers; she hopes they will serve others; she hopes that they will be sustained by their relationships with their history and culture. These hopes, however, never settle into desires for the finite outcomes that would allow her to appraise her success with each student. Instead of the consolations of expectation, Sharon manifests infinite hope, a patient and courageous hope, based on interest and curiosity. Open to the surprise of time, this hope is realistic about our place in the world; not projecting abstract fantasies onto 
the future, it is a hope that accepts tomorrow as the unfolding of the as yet unknown significance of the present.

Sharon's teaching doubtless has 'successful' outcomes, but to achieve them she sets expectations aside in her daily classroom work, concentrating simply on the students as they are, here and now. Her task as teacher is to establish a classroom in which students can be changed through their encounter with books and ideas and techniques. If she tries to control the outcome of this relation, she will close its creative potential, by insisting on its return to the same.

Education is marked by a tension between the guarantees of gift exchange and the acceptance and openness of the gift. On the one hand, people want teaching to predictably supply students with good values, with skills and knowledge, with good jobs. On the other hand, when education is based on learning, it is orientated to openness and necessarily unsettling. Many of the debates in education are beyond resolution because they are based, without acknowledgement, on this existential dilemma. In every class, good teachers hold this tension between the desire for certainty and the need for openness. They do so through their respect for the spirit in the classroom.

\section{-SPIRIT OF THE GIFT}

The concept of presence raises the question of spirit, a term that was important to classical cultural and social theory, ${ }^{51}$ but that most modern social and cultural theorists would prefer to avoid.52 While Mauss referred to the spirit of the gift, subsequent exchange theorists have criticised this aspect of his work, arguing that spirit is an unnecessary and metaphysical concept. ${ }^{53}$ In fact, Mauss himself lay the groundwork for this exclusion with his identity-based understanding of spirit:

It is clear that in Maori law, the legal tie, a tie occurring through things, is one between souls, because the thing itself possesses a soul, is of soul. Hence it follows that to make a gift of something to someone is to make a present of some part of oneself ... to accept something from somebody is to accept some part of his spiritual essence, of his soul. 54

Although Mauss uses the language of 'through' and 'between' here, he does not acknowledge the relational connotations of these terms: for him, soul and spirit are clearly possessions of things, subjects and objects. The concept of spirit adds 
nothing to his account. In other words, the meaninglessness of spirit within exchange theory derives from its failure to recognise the relationality of the gift.

From a relational perspective, exchange theory, with its focus on things, on identities, on Buber's 'It', is an abstraction from the fundamental relationality of life. Reification is a problem whether it occurs at the level of society or the individual, neither of which are commensurable with sociality. Only through the infinitude of meeting can we return from the alienation of I-It to the reality of I-Thou. As Buber says:

The fundamental fact of human existence is neither the individual nor the aggregate as such. Each, considered by itself, is a mighty abstraction. The individual is a fact of existence insofar as he steps into a living relation with other individuals. The aggregate is a fact of existence insofar as it is built up of living units of relation. The fundamental fact of human existence ... is rooted in one being turning to another, as this particular other being, in order to communicate with it in a sphere which is common to them but which reaches out beyond the special sphere of each. I call this sphere ... the sphere of 'between'.55

In this view the real reality is not things, but the no-thingness of the between: this is where life is lived. In other words, spirit is the real of sociality. As a whole, reality cannot be contained or reduced to identities. You cannot point to reality because it is no-thing, but it can be 'known' through participation, experienced as presence.

The gift is this experience of presence, the awareness of the infinitude of the whole, here and now. Sharon gives us an everyday example of this experience when she talks about the transformation in the classroom's atmosphere as it shifts from the distance of assemblage to the communion of a community. ${ }^{56}$ Participants 'work together as a whole and accept the difference in each other. That's when you see amazing opportunities.' This is a transformative experience of the whole that is characterised by a sense of belonging, and a sense of 'something more' going on, a sense of significance. These 'amazing opportunities' are the gift. Classroom spirit cannot be located in any participant, but comes through and between them all. Sharon's metaphor of the wave is an accurate description of the logic of this spirit: each participant embodies, carries and is carried by the whole. 
When Julie speaks of a spirit that is alive and well for her, she too is referring to a sense of meaningfulness, calling or belonging. This sense relies on the temporality of the eternal and original, which is whole and given yet always unfolding and unfinished. ${ }^{57}$ Without this spirit, life is alienated, stranded in a Euclidean chronological world of things, the reduced world of exchange theory's 'obligations' and 'voluntary acts'. As Godbout says, 'the gift is the very definition of life. It is the concrete and day-to-day act that binds us to the cosmos, that breaks with dualism and reconnects us to the world ... The gift is a renewed contact with the source of life and universal energy.' Without 'the spirit of the gift', he says, things circulate without any binding or connection. Without spirit, there is no gift. 58

Ann Game and Andrew Metcalfe are associate professors who teach and write together in the School of Sociology and Anthropology, University of New South Wales, Sydney. They have written four books collaboratively: Passionate Sociology; The Mystery of Everyday Life; The First Year Experience; and Teachers Who Change Lives. Additionally, Ann is co-author of Gender at Work and author of Undoing the Social, and Andrew is author of For Freedom and Dignity. <a.game@unsw.edu.au> <a.metcalfe@unsw.edu.au>

\section{-ACKNOWLEDGEMENTS}

We thank the students and teachers whom we interviewed for this research, particularly Julie McCrossin and Sharon Cheers. They are not, however, responsible for our interpretations of what they said.

-NOTES

1 Marcel Mauss, The Gift, W.W. Norton, New York, 1990, pp. 13-14 ; Claude Lévi-Strauss, The Elementary Structures of Kinship, Beacon Press, Boston, 1969, pp. 52-68; Mary Douglas, 'Foreword', in Mauss.

2 John Shotter, “'Real Presences”: Meaning as Living Movement in a Participatory World', Theory and Psychology, vol. 13, no. 3, 2003, pp. 359-92.

${ }^{3}$ Andrew Metcalfe and Ann Game, Teachers Who Change Lives, Melbourne University Press, Melbourne, 2006.

${ }^{4}$ Adriaan Peperzak, 'Giving', in Edith Wyschogrod, Jean-Joseph Goux and Eric Boynton (eds), The Enigma of Gift and Sacrifice, Fordham University Press, New York, 2002, p. 164. See also Chris Gregory, Gifts and Commodities. Academic Press, London, 1982, p. 41. 
5 Mauss, p. 82.

6 Mauss, p. 82

7 Mauss, p. 82.

${ }^{8}$ Douglas, p. vii. See also Richard Sennett, Respect: The Formation of Character in a World of Inequality, Penguin, London, 2004, pp. 219-22.

9 Jacques Derrida, Given Time, University of Chicago Press, Chicago, 1994, pp. 11-12.

10 Derrida, p. 28. See Georg Wilhelm Friedrich Hegel, Phenomenology of Spirit, Oxford University Press, Oxford, 1977, pp. 104-19.

11 Derrida, pp. $123,11-12$

12 Derrida, p. 11.

13 Derrida, p. 24.

14 Derrida, p. 16.

15 Derrida, p. 16.

16 Derrida, p. 35.

17 Derrida, p. 31.

18 Hélène Cixous, 'Sorties', in H. Cixous and C. Clement, The Newly Born Woman, University of Minnesota Press, Minneapolis, 1986, pp. 91-2.

19 Cixous, p. 87.

${ }^{20}$ Alan Schrift (ed.), The Logic of the Gift, Routledge, New York, 1997, p. 11; Georges Bataille, Visions of Excess, University of Minnesota Press, Minneapolis, 1985, pp. 118-23; Jacques Derrida, The Gift of Death, University of Chicago Press, Chicago, 1995, pp. 102-6.

21 Martin Buber, I and Thou, Scribner's, New York, 1958, pp. 3-12.

22 Buber, p. 4.

23 Buber, p. 14-15.

24 Buber, p. 11.

25 Buber, p. 12.

26 See also Martin Heidegger, On Time and Being, Harper and Row, New York, 1972, pp. 10-11; David Loy, 'What's Wrong with Being and Time: A Buddhist critique', Time and Society, vol. 1. no. 2, pp. 23956.

27 See Mircea Eliade, The Myth of Eternal Return, Princeton University Press, Princeton, 1971; John Berger, And Our Faces, My Heart, Brief as Photos, Vintage, New York, 1971.

${ }^{28}$ Gaston Bachelard, The Poetics of Space, Beacon Press, Boston, 1969.

29 Bataille, pp. 118-23.

30 Buber, p. 11.

31 David Bohm, Unfolding Meaning, Routledge, London, 1985, p. 175.

32 Derrida, Given Time, pp. 31, 123.

${ }^{33}$ Nel Noddings, Caring: A Feminine Approach to Ethics and Moral Education, University of California Press, California, 1984, p. 177.

34 Emmanuel Levinas with Phillip Nemo, Ethics and Infinity, Duquesne University Press, Pittsburgh, 1985, pp. 85-7.

35 Buber, p. 11.

36 See Lewis Hyde, The Gift, Vintage, New York, 1979, pp. 11-24; Gregory Bateson, Steps to an Ecology of Mind, Paladin, Frogmore, 1972.

37 Bataille, 1985; Levi-Strauss, 1969.

38 Jacques Godbout, The World of the Gift, McGill-Queen's University Press, Montreal, 1998, pp. 144-5.

${ }^{39}$ See Michel Serres, Angels: A Modern Myth, Flammarion, Paris, 1995, pp. 161-6.

40 See Carl Jung, 'The Shadow' in Aion: Researches into the Phenomenology of the Self, second edition, Princeton University, Press New York, 1959, pp. 8-10. 
${ }^{41}$ Raimond Gaita, 'Love and Learning and Realism', Keynote Address, Australia Catholic University, SubFaculty of Philosophy and Theology, Teaching and Learning Symposium, 14-15 April 2004.

42 See Daniel Liston, 'Love and Despair in Teaching', Educational Theory, vol. 50, no.1, 2000, pp. 81-102; Iris Murdoch, The Sovereignty of Good, Routledge \& Kegan Paul, London, 1970; Parker Palmer, To Know As We Are Known, HarperCollins, San Francisco, 1993.

43 Martin Buber, Between Man and Man, Routledge, London, 2002, p. 3.

44 Bachelard, pp. xi-xxxv.

45 George Steiner, Real Presences, Faber, London, 1989, p. 143; cf Thomas Stearns Eliot, Selected Essays, Faber and Faber, London, 1951, pp. 14-15; Shotter; Eliade.

46 Derrida, Given Time, p. 30.

${ }^{47}$ Hyde, pp. 20-1.

48 Steiner, p. 142.

${ }^{49}$ See Jean-Luc Marion, Being Given, Stanford University Press, Stanford, 2002; Shotter.

50 Murdoch, pp. 86-93.

51 For example, Emile Durkheim, The Elementary Forms of the Religious Life, Allen \& Unwin, London, 1976.

52 See Jacques Derrida, Of Spirit, University of Chicago Press, Chicago, 1991, pp. 3-4.

53 Claude Lévi-Strauss, Introduction to the Work of Marcel Mauss, Routledge \& Kegan Paul, London, 1987, p. 47; Marshall Sahlins, 'The Spirit of the Gift', in Schrift.

54 Mauss, p. 12.

55 Martin Buber, The Way of Response, Schocken Books, New York, 1966, p. 113.

56 Palmer, pp. xvi-xix.

57 See Eliade.

58 Godbout, pp. 219, 221. 